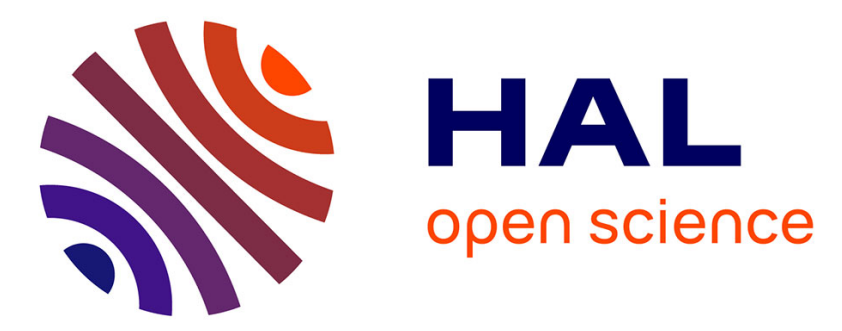

\title{
Mid-IR optical sensor for CO2 detection based on fluorescence absorbance of Dy3+:Ga5Ge20Sb10S65 fibers
}

Florent Starecki, Fréderic Charpentier, Jean-Louis Doualan, Lionel Quetel, Karine Michel, Radwan Chahal, Johann Troles, Bruno Bureau, Alain Braud, Patrice Camy, et al.

\section{To cite this version:}

Florent Starecki, Fréderic Charpentier, Jean-Louis Doualan, Lionel Quetel, Karine Michel, et al.. Mid-IR optical sensor for CO2 detection based on fluorescence absorbance of Dy3+:Ga5Ge20Sb10S65 fibers. Sensors and Actuators A: Physical, 2015, 207 (PartA), pp.518-525. 10.1016/j.snb.2014.10.011. hal-01077740

\author{
HAL Id: hal-01077740 \\ https://hal.science/hal-01077740
}

Submitted on 2 Jul 2015

HAL is a multi-disciplinary open access archive for the deposit and dissemination of scientific research documents, whether they are published or not. The documents may come from teaching and research institutions in France or abroad, or from public or private research centers.
L'archive ouverte pluridisciplinaire HAL, est destinée au dépôt et à la diffusion de documents scientifiques de niveau recherche, publiés ou non, émanant des établissements d'enseignement et de recherche français ou étrangers, des laboratoires publics ou privés. 
Mid-IR optical sensor for $\mathrm{CO}_{2}$ detection based on fluorescence absorbance of

$\mathrm{Dy}^{3+}: \mathrm{Ga}_{5} \mathrm{Ge}_{20} \mathrm{Sb}_{10} \mathrm{~S}_{65}$ fibers

Florent STARECKI $^{1,2}$, Fréderic CHARPENTIER ${ }^{1}$, Jean-Louis DOUALAN $^{2}$, Lionel QUETEL $^{3}$, Karine MICHEL ${ }^{4}$, Radwan CHAHAL ${ }^{1}$, Johann TROLES ${ }^{1}$, Bruno BUREAU ${ }^{1}$, Alain BRAUD ${ }^{2}$, Patrice CAMY ${ }^{2}$, Virginie MOIZAN $^{1}$, Virginie NAZABAL $^{1^{*}}$

${ }^{1}$ Institut Sciences Chimiques de Rennes, Equipe Verres \& Céramiques - UMR-CNRS 6226 Université de Rennes 1-CNRS, 35042 Rennes, France

${ }^{2}$ Centre de Recherche sur les Ions, les Matériaux et la Photonique (CIMAP), UMR 6252 CEA-CNRS-ENSICaen, Université de Caen, 14050 Caen, France

${ }^{3}$ IDIL Fibers Opt, 22300 Lannion, France

${ }^{4}$ Bureau de Recherches Géologiques \& Minières, F-45060 Orléans, France

Corresponding-Author: Dr. V. Nazabal (E-mail : virginie.nazabal@univ-rennes1.fr,_Institut Sciences Chimiques de Rennes, Equipe Verres \& Céramiques - UMR-CNRS 6226 Université de Rennes 1-CNRS, 35042 Rennes, France, +33 22323 5748), 


\begin{abstract}
The $\mathrm{Dy}^{3+}$ doped $\mathrm{Ga}_{5} \mathrm{Ge}_{20} \mathrm{Sb}_{10} \mathrm{~S}_{65}$ bulk glass provides good emission efficiency in the middle infrared with a better brightness than the blackbody sources. Sulfide single index fibers doped with $\mathrm{Dy}^{3+}(500-3000 \mathrm{ppm})$ were drawn with optical attenuation of about $1-3 \mathrm{~dB} / \mathrm{m}$, suitable to develop fluorescence sources for chemical analysis by optical absorption in middle infrared. They particularly present a broad emission around $4-5 \mu$ m, making them attractive for $\mathrm{CO}_{2}$ detection. Considering the low cost and efficient $\mathrm{Dy}^{3+}$ pumping scheme by means of a commercial laser diode, the $\mathrm{Dy}^{3+}$ sulfide fiber reveals potential for developing a $\mathrm{CO}_{2}$ optical sensor. Using the $4.35 \mu \mathrm{m}$ broad emission of a $\mathrm{Dy}^{3+}$ doped $\mathrm{Ga}_{5} \mathrm{Ge}_{20} \mathrm{Sb}_{10} \mathrm{~S}_{65}$ fiber combined with a differential measurement technique, the $\mathrm{CO}_{2}$ gas concentration measurement was carried out fruitfully. For this specific application, the $\mathrm{CO}_{2}$ detection threshold was fixed at about $400 \mathrm{ppm}$ corresponding to atmospheric concentration and was successfully reached for a cell length of $1.5 \mathrm{~cm}$ with a resolution of about $5 \%$. The sensitivity of the set-up is mainly related to the size of the cell, deliberately reduced to develop a robust and compact system for natural geological sites.
\end{abstract}

\title{
Keywords:
}

Mid-IR optical sensor, Rare earth, Dysprosium, $\mathrm{CO}_{2}$ detection, Chalcogenide glass, Chalcogenide fibers 


\section{Introduction}

The implication of greenhouse gas emissions in global warming is well established with carbon dioxide rate in the atmosphere, currently around $380 \mathrm{ppm}$, continually increasing. Thus, the deployment of effective carbon mitigation technologies is required to substantially diminish emissions from fossil fuel recovery and use. Only the common achievement of the renewable energy technologies development, nuclear power with its own harsh nuisances, carbon capture and storage would achieve $19 \%$ of the total emissions reductions required until 2050. To reach this level, there will be a need to capture and store $10 \mathrm{Gt}$ of $\mathrm{CO}_{2}$ per year in 2050. One possibility to store the carbon dioxide produced by human activity is to inject supercritical $\mathrm{CO}_{2}$ in underground geologic formations. As the supercritical $\mathrm{CO}_{2}$ exhibits behavior of both a gas and a liquid, it can interact chemically with the mineral components of the host rock and also migrate as a fluid. Therefore, protocols and tools for safe and secure $\mathrm{CO}_{2}$ storage have to ensure that the technical staff or the local population will not be endangered by any of the activities related to $\mathrm{CO}_{2}$ emission within the storage complex. These geologic reservoirs, aquifers and wells have to be monitored for a long-term period in order to potentially detect leaks occurring during the $\mathrm{CO}_{2}$ injection or appearing during the storage and some international research projects are focused on this thematic; as for instance, the $\mathrm{CO}_{2} \mathrm{CARE}$ project, financed by the $7^{\text {th }}$ FPRD concerning the procedures and technologies for sealing and long-term safety of $\mathrm{CO}_{2}$ storage sites. At this time, no commercial solution is enough efficient to ensure a really helpful $\mathrm{CO}_{2}$ detection for several reasons: cost, versatility, ageing, instantaneous response, temperature robustness, etc. Although several methods have proven to be efficient for the $\mathrm{CO}_{2}$ sensing, such as by means of a fiber with a dip coated sensitive film containing the $\mathrm{CO}_{2}$ indicator or fiber tips combined with capillary reservoirs, a method widely used for the carbon dioxide monitoring in classical condition is a technology 
based on the optical absorption of $\mathrm{CO}_{2}$ around $4.3 \mu \mathrm{m}$ [1-3]. Thus, the $\mathrm{CO}_{2}$ concentration can be deduced by measuring the transmission at this middle infrared (mid-IR) wavelength through a $\mathrm{CO}_{2}$ cell. This had been reported by Blomberg et al. set on the single beam dual wavelength technique and thus using a micro-machined Fabry-Perot interferometer [4]. The mid-IR radiation is generated by black body sources, which are directly dependent upon the temperature. To perform an optical detection, their brightness is low and strongly influenced by the surrounding. Consequently, black body sources are not really suitable for such environmental application, and could be favorably replaced by rare earth doped chalcogenide fibers.

Trivalent rare earths ions $4 \mathrm{f}$-shell transitions can generate light from UV to Mid-IR, depending on their host and intrinsic energy scheme, so it can be used to replace the Mid-IR sources in optical devices. The brightness depends on the optical pump source and is relatively independent of the temperature. Among all the rare earth, the Dy ${ }^{3+}$ presents an emission band centered at $4.35 \mu \mathrm{m}$ corresponding to the transition between the ${ }^{6} \mathrm{H}_{11 / 2}$ and ${ }^{6} \mathrm{H}_{13 / 2}$ levels, giving a good overlap with the $\mathrm{CO}_{2}$ absorption band at $4.3 \mu \mathrm{m}$ [5-9]. In glasses, their emissions are broad and low structured which is favorable for a differential detection technique where a spectral range not affected by the absorption of the molecule can be used as the reference of the optical sensor. Furthermore, optical fiber can be fabricated from rare earth ions doped Ge-Ga-Sb-S glass preform that increases the brightness of the source [10-12].

For a transmission and emission in this $3-5 \mu \mathrm{m}$ wavelength range, the glass must provide a low phonon energy, which eliminates thereby the classical silica fibers. The germanium based sulfide glasses are intrinsically good candidates, as sulfide had low phonon energy of about $\hbar \omega \sim 340 \mathrm{~cm}^{-1}$, present a flat transmission band between 1 and $11 \mu \mathrm{m}$, and provides mid-IR emission thanks to a low probability of multiphonon relaxation. Besides, the Ga-Ge-Sb-S glasses can be shaped in waveguides, like planar and rib waveguides or optical fibers and 
light can be easily confined into high refractive index structures $(\sim 2.25$ at $1.5 \mu \mathrm{m})[10,13$ 18]. Moreover, in such glasses, the incorporation of rare earth ions is possible up to 10000 ppm, while preserving the amorphous state of the material.

In this present paper, the fabrication and spectroscopic properties of the $\mathrm{Dy}^{3+}$ doped $\mathrm{Ga}_{5} \mathrm{Ge}_{20} \mathrm{Sb}_{10} \mathrm{~S}_{65}$ glasses and fibers are presented and the manufacturing and assessment of an optical sensor devoted to $\mathrm{CO}_{2}$ detection in natural site is detailed.

\section{Materials and methods}

\section{1. $\mathrm{Dy}^{3+}: \mathrm{Ga}_{5} \mathrm{Ge}_{25} \mathrm{Sb}_{10} \mathrm{~S}_{65}$ bulk glass and fibers fabrication}

The chemical composition of the sulfide glass is $\mathrm{Ga}_{5} \mathrm{Ge}_{20} \mathrm{Sb}_{10} \mathrm{~S}_{65}$, doped by $\mathrm{Dy}^{3+}$ in the range from 1000 to $10000 \mathrm{ppm}$. High purity raw materials were used for glass preparation, i.e. $5 \mathrm{~N}$ for germanium, gallium, antimony or sulfur and $3 \mathrm{~N}$ for dysprosium sulfide. The glasses were synthesized by conventional melt quenching. The sulfur was firstly evaporated at $350^{\circ} \mathrm{C}$ for purification. After sealing, the silica tube was heated to $950^{\circ} \mathrm{C}$ several hours and sufficiently rapidly cooled to prevent crystallization phenomenon within the glass. The annealing temperature is slightly kept below their glass transition temperature for several hours $\left(295^{\circ} \mathrm{C}\right)$, to reduce the mechanical stresses induced by the quenching. The $300-400 \mu \mathrm{m}$ single index fibers were obtained by drawing $\mathrm{Ga}_{5} \mathrm{Ge}_{20} \mathrm{Sb}_{10} \mathrm{~S}_{65}$ glass performs of $12 \mathrm{~mm}$ diameter and $100 \mathrm{~mm}$ length [10, 11]. Fiber attenuation measurements on unclad Dy-doped fibers were performed by using the cut-back technique with a Bruker FTIR spectrometer modified with fiber coupling ports.

\subsection{Spectroscopic characterization}


The absorption cross-section spectrum of a $\mathrm{Dy}^{3+}$ doped $\mathrm{Ga}_{5} \mathrm{Ge}_{20} \mathrm{Sb}_{10} \mathrm{~S}_{65}$ bulk glass was recorded using a Perkin Elmer Lambda 1050 spectrophotometer (Figure 1). A classical measurement setup composed of a chopped Ti-Sa laser emitting at $920 \mathrm{~nm}$ has been used to record the emission spectrum from 950 to $5000 \mathrm{~nm}$ of $\mathrm{Dy}^{3+}: \mathrm{Ga}_{5} \mathrm{Ge}_{20} \mathrm{Sb}_{10} \mathrm{~S}_{65}$ bulk glass and fibers, by means of a cooled InSb detector combined with a monochromator and a lock-in amplifier (Figure 2). For lifetime measurements, the excitation source was a tunable GWU C$355 \mathrm{OPO}$, producing $6 \mathrm{~ns}$ pulses at a rate of $10 \mathrm{~Hz}$ and triggering the oscilloscope for decay recordings.

\subsection{Mid-IR optical sensor set up}

The sensor is composed of a Y separator terminated by SMA or FC/APC connectors and contained a $\mathrm{Dy}^{3+}$ doped chalcogenide fiber and an undoped chalcogenide fiber (Figure 3). It's connected to a fiber laser diode, a detector and a gas cell. An Axcel Photonics 1.5W laser diode emitting at $920 \mathrm{~nm}$ is used to pump a $20 \mathrm{~cm}$ length $1000 \mathrm{ppm} \mathrm{Dy}^{3+}$ doped $\mathrm{Ga}_{5} \mathrm{Ge}_{20} \mathrm{Sb}_{10} \mathrm{~S}_{65}$ fiber. This wavelength tune, compared to the absorption maximum located at $915 \mathrm{~nm}$, is adjusted by controlling the diode operating temperature to have a better overlap between the diode emission band and the absorption spectrum.

Using a low-losses silica fiber to carry the pumping beam, a remote excitation could be performed without significant attenuation of the pump beam The fiber pump is connect to the chalcogenide $\mathrm{Dy}^{3+}$ fiber. The incoherent $4.3 \mu \mathrm{m}$ fluorescence signal emitted by the fiber is collimated in the gas cell using typically an aspheric chalcogenide lens with a $\mathrm{f}=0.6 \mathrm{~cm}$ focal length. An adjustable position plane mirror governs the cell length L, which depends on the expected measurement range (see 3.2.3). The reflected beam is focused in the undoped chalcogenide fiber. Thus, the absorption-modified $4.3 \mu \mathrm{m}$ signal can be brought to an Infratec LFP-3950L-337 pyroelectric detector, which entrance window integrates an electrically 
tunable Fabry-Perot resonator $(\mathrm{FWHM}=80 \mathrm{~nm})$ shifting the three wavelengths for $\mathrm{V}(\mathrm{x}), \mathrm{V}_{\text {ref }}$ and $\mathrm{V}_{\mathrm{b}}$ signal measurement. For operations inside the wells; this device is packaged into a host tube, drilled to enable gases flowing in and both electrical and optical wires exceed $100 \mathrm{~m}$.

\section{Results and discussion}

\subsection{Spectroscopy of Dysprosium ions in sulfide host glass}

\subsection{1. $\mathrm{Dy}^{3+}: \mathrm{Ga}_{5} \mathrm{Ge}_{20} \mathrm{Sb}_{10} \mathrm{~S}_{65}$ bulk glass and fibers}

The absorption cross-section spectrum of a $\mathrm{Dy}^{3+}$ doped $\mathrm{Ga}_{5} \mathrm{Ge}_{20} \mathrm{Sb}_{10} \mathrm{~S}_{65}$ bulk glass is reported in Figure 1. Limited by the absorption edge in visible range of the host sulfide glass, four main absorption bands are observed located at $0.92,1.1,1.3$ and $1.7 \mu \mathrm{m}$, corresponding respectively to the transitions between the ground state ${ }^{6} \mathrm{H}_{15 / 2}$ and the ${ }^{6} \mathrm{~F}_{7 / 2},\left({ }^{6} \mathrm{~F}_{9 / 2}+{ }^{6} \mathrm{H}_{7 / 2}\right)$, $\left({ }^{6} \mathrm{~F}_{11 / 2}+{ }^{6} \mathrm{H}_{9 / 2}\right)$ and ${ }^{6} \mathrm{H}_{11 / 2}$ levels. From the integrated absorption cross-sections over each manifold, a Judd-Ofelt analysis has been performed to estimate the spectroscopic parameters (radiative lifetime and branching ratio) of the radiative levels (Table 1) [19, 20]. The estimated Judd-Ofelt parameters $\left(\Omega_{2}=11.4 \times 10^{-20}, \Omega_{4}=2.2 \times 10^{-20}\right.$ and $\left.\Omega_{6}=3.1 \times 10^{-20} \mathrm{~cm}^{2}\right)$, for the $\mathrm{Dy}^{3+}$ in the $\mathrm{Ga}_{5} \mathrm{Ge}_{25} \mathrm{Sb}_{10} \mathrm{~S}_{65}$ host glass, are comparable to those found in the literature for sulfide matrices [21, 22]. The important value of the parameter $\Omega_{2}$ in sulfides matrices reflects the high degree of covalence of the ligands/rare earth bonds. Lifetimes, multiphonon rates, and quantum efficiencies for the ${ }^{6} \mathrm{H}_{7 / 2},{ }^{6} \mathrm{H}_{9 / 2},{ }^{6} \mathrm{H}_{11 / 2}$ and ${ }^{6} \mathrm{H}_{13 / 2}$ excited levels are also given in Table 1 and discussed, in the following section, with respect to the mid-IR emission for the purpose of detecting $\mathrm{CO}_{2}$.

The emission spectrum of $\mathrm{Dy}^{3+}: \mathrm{Ga}_{5} \mathrm{Ge}_{20} \mathrm{Sb}_{10} \mathrm{~S}_{65}$ glass from 1200 to $5000 \mathrm{~nm}$ is presented in Figure 2 with excitation at $915 \mathrm{~nm}$ of the ${ }^{6} \mathrm{~F}_{7 / 2}$ level. The major contributions that could be observed on the emission spectrum corresponds to emissions from the excited manifold to the 
${ }^{6} \mathrm{H}_{15 / 2}$ ground state level (Figure 1). The presented near-IR and mid-IR emissions are related to the three transitions: ${ }^{6} \mathrm{~F}_{11 / 2}+{ }^{6} \mathrm{H}_{9 / 2} \rightarrow{ }^{6} \mathrm{H}_{15 / 2}(1.35 \mu \mathrm{m}),{ }^{6} \mathrm{H}_{11 / 2} \rightarrow{ }^{6} \mathrm{H}_{15 / 2}(1.76 \mu \mathrm{m})$ including probably a small contribution from the ${ }^{6} \mathrm{~F}_{9 / 2}+{ }^{6} \mathrm{H}_{7 / 2} \rightarrow{ }^{6} \mathrm{H}_{13 / 2}$ transition, and ${ }^{6} \mathrm{H}_{13 / 2} \rightarrow{ }^{6} \mathrm{H}_{15 / 2}(2.87$ $\mu \mathrm{m})$. Finally, the ${ }^{6} \mathrm{H}_{11 / 2} \rightarrow{ }^{6} \mathrm{H}_{13 / 2}$ transition is observed around $4.35 \mu \mathrm{m}$. In Figure $2 \mathrm{~B}$, the black line has been recorded using an $\mathrm{N}_{2}$-purged box, but still witnesses some traces of $\mathrm{CO}_{2}$ absorption.

The fluorescence lifetimes were experimentally investigated for the bulk glasses with different concentration of $\mathrm{Dy}^{3+}$ ranging from 1000 to $10000 \mathrm{ppm}$. The fluorescence decay of the ${ }^{6} \mathrm{~F}_{7 / 2}$ level could not be detected, with excitation at $815 \mathrm{~nm}$, showing an efficient energy transfer to the lower levels. The ${ }^{6} \mathrm{H}_{7 / 2}$ decay, pumped at $915 \mathrm{~nm}$, shows a huge noise but gave a constant fluorescence time $(3 \mu \mathrm{s})$ close to the calculated value (Table 1). The decays recorded at the three wavelengths $\left(1.35 \mu \mathrm{m},{ }^{6} \mathrm{H}_{9 / 2} ; 1.76 \mu \mathrm{m},{ }^{6} \mathrm{H}_{11 / 2} ;\right.$ and $\left.2.87 \mu \mathrm{m},{ }^{6} \mathrm{H}_{13 / 2}\right)$ typically shows a rise time from a $915 \mathrm{~nm}\left({ }^{6} \mathrm{~F}_{7 / 2}\right)$ pumping (Table 2). These rise times are in the tenth nanosecond range for the ${ }^{6} \mathrm{H}_{9 / 2}$ and ${ }^{6} \mathrm{H}_{11 / 2}$ manifolds. It is about $38 \mu$ s for the ${ }^{6} \mathrm{H}_{11 / 2}$ manifold for a $1000 \mathrm{ppm} \mathrm{Dy}^{3+}$ doped glass. As the doping level increases, their rise time is decreasing in the same proportions than their fluorescence lifetime. Indeed, the fluorescence lifetimes of the three excited levels $\left({ }^{6} \mathrm{H}_{9 / 2},{ }^{6} \mathrm{H}_{11 / 2}\right.$, and $\left.{ }^{6} \mathrm{H}_{13 / 2}\right)$ feature a gradual decrease, particularly pronounced for higher concentration than 5000 ppm for the ${ }^{6} \mathrm{H}_{11 / 2}$ and ${ }^{6} \mathrm{H}_{13 / 2}$ levels. From a $5000 \mathrm{ppm}$ to a $10000 \mathrm{ppm} \mathrm{Dy}{ }^{3+}$ doped glass, the ${ }^{6} \mathrm{H}_{11 / 2}$ lifetime falls from $1.4 \mathrm{~ms}$ to $0.6 \mathrm{~ms}$ (Table 2). It was reported from EXAFS analysis that the site around Dysprosium ions in $\mathrm{Ga}_{5} \mathrm{Ge}_{20} \mathrm{Sb}_{10} \mathrm{~S}_{65}$ host matrix changes from a coordination number of $7.9 \pm 0.5$ sulfur atoms for a concentration of $\sim 10000 \mathrm{ppm}$ of $\mathrm{Dy}^{3+}$ to $6.3 \pm 0.5$ for a lower concentration $(\sim 1000 \mathrm{ppm})$, corresponding to optical fibers doping [10]. Without affecting the bond lengths, such environment variation of $\mathrm{Dy}^{3+}$ ions with increasing concentration may traduce dipole-dipole 
distance shortening for high Dy concentrations, which is expected to influence fluorescence efficiency and lifetime by energy transfers.

The $\mathrm{Ga}_{5} \mathrm{Ge}_{20} \mathrm{Sb}_{10} \mathrm{~S}_{65}$ fibers doped were drawn with $1000 \mathrm{ppm}$ and $3000 \mathrm{ppm}$ of $\mathrm{Dy}^{3+}$ ions and have shown a minimum optical losses around $1-3 \mathrm{~dB} / \mathrm{m}$ in mid-IR. The attenuation curves present expected absorption bands associated to the presence of dysprosium but also related to impurities in the host matrix. Characteristic vibration modes of $\mathrm{O}-\mathrm{H}, \mathrm{CO}_{2}$ and $\mathrm{C}-\mathrm{S}$ are located in the attenuation spectra between 2.1 and $2.9 \mu \mathrm{m}$, at $4.2 \mu \mathrm{m}$ and $4.95 \mu \mathrm{m}$ respectively. Finally, the vibration of S-H bonds gives absorption bands at 3.1 and $4.0 \mu \mathrm{m}$ and can be limited to $\sim 15 \mathrm{ppm}$ by purification steps [11]. Mid-IR fluorescence in the optical fibers have shown an equally efficiency compare to bulk glasses, with a net gain in terms of available light fluency at the output of the optical fibers. The $\mathrm{Ga}_{5} \mathrm{Ge}_{20} \mathrm{Sb}_{10} \mathrm{~S}_{65}$ fiber doped with 1000 ppm of $\mathrm{Dy}^{3+}$ allows to achieve the best compromise for easy implementation of purification, drawing, optical attenuation and fluorescence.

\subsubsection{Properties of $\mathrm{Dy}^{3+}$ in $\mathrm{Ga}_{5} \mathrm{Ge}_{20} \mathrm{Sb}_{10} \mathrm{~S}_{65}$ glass matrix for $\mathrm{CO}_{2}$ detection}

In order to observe the fluorescence of $\mathrm{Dy}^{3+}$ at $4.35 \mu \mathrm{m}$, it is required to pump the fundamental level to the ${ }^{6} \mathrm{H}_{11 / 2}$ level at about $1.7 \mu \mathrm{m}$, or in the upper ones. Thus, each absorption band observed in the figure 1 could be potentially exploited for the optical pumping. The criterion for selecting the suitable absorption band is to find the best compromise between the absorption cross-section, the available output power of a laser diode and the quantum yield for reaching the ${ }^{6} \mathrm{H}_{11 / 2}$ level. Regarding the second reason, the direct pumping of the ${ }^{6} \mathrm{H}_{11 / 2}$ using a $1.7 \mu \mathrm{m}$ laser diode is not the best solution yet. Thus, considering the high absorption cross-section of the ${ }^{6} \mathrm{H}_{15 / 2} \rightarrow\left({ }^{6} \mathrm{~F}_{11 / 2}+{ }^{6} \mathrm{H}_{9 / 2}\right)$ transition seems to be a suitable choice to pump the $\mathrm{Dy}^{3+}$ ions at $1.3 \mu \mathrm{m}$. Nevertheless, there is not enough powerful commercial laser diode emitting at this wavelength. Finally, the best agreement between the 
available pumping diodes and the corresponding $\mathrm{Dy}^{3+}: \mathrm{Ga}_{5} \mathrm{Ge}_{20} \mathrm{Sb}_{10} \mathrm{~S}_{65}$ absorption crosssection is to use a $920 \mathrm{~nm}$ laser diode with a quite affordable cost and a high output power.

The energy gaps between the successive levels $\left({ }^{6} \mathrm{~F}_{11 / 2},{ }^{6} \mathrm{H}_{9 / 2}\right),\left({ }^{6} \mathrm{~F}_{9 / 2},{ }^{6} \mathrm{H}_{7 / 2}\right),{ }^{6} \mathrm{~F}_{7 / 2},{ }^{6} \mathrm{~F}_{5 / 2}$ and ${ }^{6} \mathrm{~F}_{3 / 2}$ are about some hundreds of $\mathrm{cm}^{-1}$, and the ${ }^{6} \mathrm{H}_{5 / 2}$ absorption band is scarcely visible on the tail of the ${ }^{6} \mathrm{~F}_{7 / 2}$ band (Figure 1), and will be later on neglected. Subsequently, a low phonon energy matrix is required to decrease the multiphonon relaxation rate between the ${ }^{6} \mathrm{H}_{11 / 2}$ and ${ }^{6} \mathrm{H}_{13 / 2}$ levels and thus enhancing the $4.35 \mu \mathrm{m}$ emissions. The phonon energy should also be large enough to allow populating the emitting ${ }^{6} \mathrm{H}_{11 / 2}$ manifold through an efficient nonradiative decay from the ${ }^{6} \mathrm{H}_{9 / 2}+{ }^{6} \mathrm{~F}_{11 / 2}$. For mid-IR emissions, chalcogenide glasses proved their efficiency by reducing the multiphonon relaxation of emitting levels and the $\sim 340 \mathrm{~cm}^{-1}$ phonon energy of the sulfide glass is enough high to provide an efficient population of the ${ }^{6} \mathrm{H}_{11 / 2}$ manifold when optically pumped into higher-lying manifolds (Table 1 and 2). To be precise about phonons energy of bulk $\mathrm{Ga}_{5} \mathrm{Ge}_{20} \mathrm{Sb}_{10} \mathrm{~S}_{65}$ glass, the Raman scattering spectrum corresponds to a broad band between 260 and $450 \mathrm{~cm}^{-1}$, which is composed of several overlapping bands peaking at 295, 340, 370 and $430 \mathrm{~cm}^{-1}[16,23]$. Three main bands, with decreasing intensity from 340,370 to $430 \mathrm{~cm}^{-1}$, have been typically reported related to [ $\mathrm{GeS}_{4}$ ] tetrahedra vibration modes. Very weak Raman band observed at $485-495 \mathrm{~cm}^{-1}$ is attributed to stretching vibration of $\mathrm{S}_{8}$ rings indicating probably the formation of small number of S-S bonds. Considering these vibration modes, the levels located at higher energy than the $\left({ }^{6} \mathrm{~F}_{11 / 2}\right.$, ${ }^{6} \mathrm{H}_{9 / 2}$ ) level are strongly affected by multiphonon relaxation. Therefore, the population of these levels can be figured as negligible [22].

As already mentioned, the emission properties have been investigated using different concentration of $\mathrm{Dy}^{3+}(1000,5000$ and $10000 \mathrm{ppm})$ and the lowest doping concentration was used for lifetime measurement to limit at minimum any reabsorption or other energy transfer, e.g. involving the ${ }^{6} \mathrm{H}_{13 / 2}$ concentration quenching effect $[6,9]$. the emission bands resulting 
from the pumping at $920 \mathrm{~nm}$ present a first contribution centered at the wavelength of 1350 nm, arising from the ${ }^{6} \mathrm{H}_{9 / 2}$ manifold. A second, from the ${ }^{6} \mathrm{H}_{11 / 2}$ manifold is occurring at 1760 $\mathrm{nm}$, and a third at $2870 \mathrm{~nm}$ corresponds to the ${ }^{6} \mathrm{H}_{13 / 2} \rightarrow{ }^{6} \mathrm{H}_{15 / 2}$ transition. The main interest here is the $4.3 \mu \mathrm{m}$ fluorescence band that would be used for $\mathrm{CO}_{2}$ sensing. According to the figure 2-B, a $\mathrm{CO}_{2}$ absorption band in the spectra is visible at $4.2 \mu \mathrm{m}$, on which the detection principle relies which is due to some remaining traces of $\mathrm{CO}_{2}$ gas in the beam path. The red line shows how the wide $4.3 \mu \mathrm{m} \mathrm{Dy}^{3+}$ emission band is affected by a higher $\mathrm{CO}_{2}$ concentration.

If we consider the small energy difference between successive levels lower than excited ${ }^{6} \mathrm{~F}_{7 / 2}$ level pumped by laser diode at $920 \mathrm{~nm}$, the phonon energies of $\mathrm{Ga}_{5} \mathrm{Ge}_{20} \mathrm{Sb}_{10} \mathrm{~S}_{65}$ glasses ( $\left(\omega_{\max }\right.$ $\sim 340 \mathrm{~cm}^{-1}$ ) is leading to a non-radiative relaxation predominance from any upper level to the $\left({ }^{6} \mathrm{H}_{9 / 2},{ }^{6} \mathrm{~F}_{11 / 2}\right)$ level. As it is already described by Ichikawa et al., the optical pumping in the ${ }^{6} \mathrm{~F}_{5 / 2}$ band is leading to quite the same fluorescence spectrum than the one obtained when pumping in the ${ }^{6} \mathrm{~F}_{7 / 2}$ manifold, apart the minor ${ }^{6} \mathrm{~F}_{5 / 2} \rightarrow{ }^{6} \mathrm{H}_{13 / 2}$ fluorescence contribution [9]. The measured lifetimes have been compared to the Judd-Ofelt calculations, and are in good agreement for low concentration of $\mathrm{Dy}^{3+}$ ions representative of optical fiber doping (Table 2). From the multiphonon rate $1 / \tau_{\mathrm{MP}}$ estimation using the gap law relationship and the corresponding parameters [24], the theoretical quantum efficiency $\eta$ of the ${ }^{6} \mathrm{H}_{11 / 2}$ level is calculated at $64 \%$, using the following formula (3):

$$
\eta=\frac{\tau}{\pi}
$$

Nevertheless, this relation does not take into account the RE concentration quenching effects. Combined with the Judd-Ofelt radiative lifetime calculations, a good approximation of the fluorescence lifetime could be calculated here (4), as minor contributions from crossrelaxation assisted decays are not taken into account. These results are reported in Table 1. 


$$
\tau_{\text {fluo }}(J 0)=\tau_{\text {mad }} \cdot \eta
$$

The calculated fluorescence lifetime for the $1000 \mathrm{ppm}$ doped glass is of $1.47 \mathrm{~ms}$, while the experimental $\tau_{\text {fluo }}$ is of about $1.3 \mathrm{~ms}$. These discrepancies between calculated and experimental lifetime may be due to some impurities (mainly $\mathrm{S}-\mathrm{H}$ or $\mathrm{O}-\mathrm{H}$ bonds) and concentration quenching effects on the excited $\mathrm{Dy}^{3+}$ states, which can occur even for low dopant concentration [8]. This result is also indicating that the purifications steps are providing glasses with a low impurity density. Besides, the obtained $\tau_{\text {fluo }}$ is relevant with the latter theoretical quantum efficiency of $64 \%$.

The S-H vibration mode $\left(2400 \mathrm{~cm}^{-1}\right)$ can quench both ${ }^{6} \mathrm{H}_{13 / 2}$ and ${ }^{6} \mathrm{H}_{11 / 2}$ manifolds, but the ${ }^{6} \mathrm{H}_{13 / 2}$ emission was found to be mostly radiative, with a $\tau_{\mathrm{f}}$ of about $5.6 \mathrm{~ms}$, while the calculated value $\tau_{\text {rad }}$ is $7.0 \mathrm{~ms}$, witnessing both few impurities and a cross relaxation quenching. All the reported decays are exhibiting rise times, typically in the microsecond range for the ${ }^{6} \mathrm{H}_{9 / 2}$ rise time, and in the 30 microseconds range for the ${ }^{6} \mathrm{H}_{11 / 2}$ manifold population after a $915 \mathrm{~nm}$ pumping. The ${ }^{6} \mathrm{H}_{13 / 2}$ decay also shows a rise time, corresponding to the incoming population from the upper ${ }^{6} \mathrm{H}_{11 / 2}$, and lasting more than one millisecond. These results are in good agreement with the ones reported by Ichikawa et al. for a similar $\mathrm{Ga}_{7} \mathrm{Ge}_{18} \mathrm{Sb}_{11} \mathrm{~S}_{64}$ glass and Shin et al for a $\mathrm{Ga}_{5} \mathrm{Ge}_{30} \mathrm{~S}_{64}$ or $\mathrm{Ga}_{10} \mathrm{Ge}_{25} \mathrm{~S}_{65}$ glasses $[6,9,22]$. Nevertheless, it can be noticed that the quantum efficiency of ${ }^{6} \mathrm{H}_{13 / 2}$ is higher than those reported by these authors.

For $\mathrm{Ga}_{5} \mathrm{Ge}_{20} \mathrm{Sb}_{10} \mathrm{~S}_{65}$ glass, the multiphonon relaxation rates, related to the pure vibration modes of the matrix, should be a predominant decay mechanism among the excited states if the energy gap to the next lower level is smaller than $1700 \mathrm{~cm}^{-1}$. For an energy gap larger than $1700 \mathrm{~cm}^{-1}$, additional non-radiative decay processes become dominant over the multiphonon decay. Indeed, given the energy gap for the transition ${ }^{6} \mathrm{H}_{13 / 2} \rightarrow{ }^{6} \mathrm{H}_{15 / 2}$ and ${ }^{6} \mathrm{H}_{11 / 2} \rightarrow{ }^{6} \mathrm{H}_{13 / 2}\left(3489 \mathrm{~cm}^{-1}\right.$ and $2358 \mathrm{~cm}^{-1}$, respectively), the ${ }^{6} \mathrm{H}_{11 / 2}$ level is really sensitive to the 
presence of impurities in the glass, especially $[\mathrm{S}-\mathrm{H}]$ bonds $\left(\sim 2400 \mathrm{~cm}^{-1}\right)$ inducing nonradiative relaxation. The efficiency of the method of purification used for $\mathrm{Ga}_{5} \mathrm{Ge}_{20} \mathrm{Sb}_{10} \mathrm{~S}_{65}$ glasses $([\mathrm{SH}]<20 \mathrm{ppm})$ is thus reflected in the quantum efficiency of these two levels. The high purification can mitigate the diffusion-limited relaxation for which the impurity concentration is considered much lower than the rare earth ions one. Only a small fraction of RE-acceptor transfer probability is being treated as compared to a RE-RE one [24]. To achieve laser operation on this self-terminating transition, the population depleting of the ${ }^{6} \mathrm{H}_{13 / 2}$ could be enhanced using an appropriate doping concentration, to take advantage of the concentration quenching effect, what is strongly affecting transitions involving the groundstate [9].

\subsection{Optical sensor for $\mathrm{CO}_{2}$ detection based on $\mathrm{Dy}^{3+}$ : $\mathrm{Ga}_{5} \mathrm{Ge}_{25} \mathrm{Sb}_{10} \mathrm{~S}_{65}$ glass.}

\subsubsection{Background of the $\mathrm{CO}_{2}$ measurement}

The operation of the $\mathrm{CO}_{2}$ optical sensor is based on the Beer-Lambert's absorption law, as the $4.3 \mu \mathrm{m}$ guided fluorescence signal fulfills the small-signal conditions. The $\mathrm{CO}_{2}$ concentration can be determined by comparing the fluorescence intensity at two wavelengths $\lambda_{\text {abs }}$ and $\lambda_{\text {ref, }}$, the first within the $\mathrm{CO}_{2}$ absorption band $(\mathrm{V}(\mathrm{x}))$, and the second without $\left(\mathrm{V}_{\text {ref }}\right)$

(Figure 2-B). The measurement is corrected from the background noise using a third measurement at $\lambda_{\mathrm{b}}$ out of the $\mathrm{Dy}^{3+}$ fluorescence spectra $\left(\mathrm{V}_{\mathrm{b}}\right)$. The differential measurement between the $\mathrm{CO}_{2}$ absorption band and the reference avoids the variation of signal intensity, the following quantity $\mathrm{R}(\mathrm{x})$ behaves identically

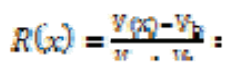


Where $\mathrm{I}(\mathrm{x})$ and $\mathrm{I}_{\text {ref }}$ is the signal intensity. The signal intensity $\mathrm{I}_{\text {ref }}$ isn't depending of the $\mathrm{CO}_{2}$ absorption then the ratio between the cell with and without $\mathrm{CO}_{2}$ is proportional to the BeerLambert's law

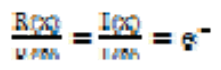

Where $\alpha(x)$ is the $\mathrm{CO}_{2}$ absorption coefficient and $\mathrm{L}$ the cell length. With this formula it is possible to determine the $\mathrm{CO}_{2}$ concentration from the detector's output voltage.

\subsubsection{Experimental methodology of the optical sensor}

The first experiment to test the feasibility of the $\mathrm{CO}_{2}$ optical sensor has been done with a classical fluorescence measurement set-up, allowing the monitoring, at the same time by a reference device, of the signal at $4.35 \mu \mathrm{m}$ emitted by a $\mathrm{Ga}_{5} \mathrm{Ge}_{20} \mathrm{Sb}_{10} \mathrm{~S}_{65}: \mathrm{Dy}^{3+}$ fiber through a $4 \mathrm{~mm}$ cell filled with a mixture of $\mathrm{CO}_{2}$ and $\mathrm{N}_{2}$ gas. All the fluorescence spectra is measured (Figure 2-B) by subtracted a spectra without $\mathrm{CO}_{2}$ it is possible to determine the concentration in the cell. With this approach, it is possible to detect a 50ppm $\mathrm{CO}_{2}$ concentration with a long path of $4 \mathrm{~mm}$. A better sensitivity is possible with a thicker cell.

The next step was to compact the whole sensor device in a first prototype in order that it can be used in outside natural site without any cumbersome lock-in devices and monochromator. For this mid-IR spectral range, a RT compact pyroelectric detector is suitable, and can replace the $\mathrm{N}_{2}$-liq cooled $\mathrm{InSb}$ detector. Since a pyroelectric detector responds to optical flux variations, a condition for a well-use is to apply a modulated signal. The monochromator was replaced by a compact and electrically tunable Fabry-Pérot (FP) air cavity micro-resonator, integrated to the pyroelectric detector. The FP is composed of the fix mirror and a spring mounted mirror. The voltage difference applied to the mirrors modifies the air space distance between them and change the maximum wavelength transmission of the filter. The signal is 
measurement at three wavelengths, at $4.35 \mu \mathrm{m}$ in the absorption band of the $\mathrm{CO}_{2}(\mathrm{~V}(\mathrm{x}))$, at $4.35 \mu \mathrm{m}$ for reference $\left(\mathrm{V}_{\text {ref }}\right)$ and at $4 \mu \mathrm{m}$ outside the emission band of $\mathrm{Dy}^{3+}$ for the background $\left(\mathrm{V}_{\mathrm{b}}\right)$. One of the limits of this compact detector is due to the FP microresonator. The mirror mounted on the spring is position dependent, the gravity force applied to this mirror change its position relative to the fixed one, and it's induced a difference in the wavelength maximum transmission when the detector position is modified. The wavelength variation between vertical and horizontal position is typically $20 \mathrm{~nm}$, the knowledge of detector position is very important for calibration and measurement.

The pyroelectric detector is sensitive to the variation of signal. It is therefore necessary to modulate the fluorescence from the fiber which is achieved by modulating the pump diode. The signal from the detector is measured and saved. As the operating frequencies are low, it is easy to make interfacing with a computer. A Labview program drive the diode modulation, the voltage applied to the FP for selecting a wavelength, and measures the sensor signal. The modulation signal of the diode $(15 \mathrm{~Hz})$ is used for synchronization of the measurement (Figure 4). After a delay, the signal is measured and averaged. To avoid fluctuations the signal is recorded every half cycle and the difference is retained. For each wavelength, some values are recorded and averaged. The time to sweep the FP on the entire range of wavelength (3900- $4900 \mathrm{~nm}$ ) is $450 \mathrm{~ms}$. In the experiment, the selected spectral range is only between 4000 and $4500 \mathrm{~nm}$. During the FP movement between two wavelengths, a delay of $250 \mathrm{~ms}$ is waited before the measurement. The program gives the final values of the signals at the three wavelengths $\lambda_{\text {abs }}, \lambda_{\text {ref }}$ and $\lambda_{\mathrm{b}}$ and the ratio $\mathrm{R}(\mathrm{x})$ (1). The minimum time measurement for a $\mathrm{CO}_{2}$ concentration value is around 1s, a longer time increases the useful time for the acquisition thereby improves the statistical and get a less noisy signal.

\subsubsection{Mid-IR sensor efficiency assessment}


The sensor is first tested indoor. Its gas cell is introduced in a chamber with a $\mathrm{N}_{2}$ and $\mathrm{CO}_{2}$ mixed gas flow. The optical sensor shows a good accuracy and temporal response. Its calibration has been performed by means of three standard $\mathrm{CO}_{2}$ concentrations $(500,1000$ and 5000ppm). Indeed, the gas cell length was designed for atmospheric concentrations measurements. The cell length governs the linear measuring range, and the linearity loss in the detector calibration for value higher than $1000 \mathrm{ppm}$ can be explained by the fact that the $\mathrm{CO}_{2}$ absorption bands do not affect the measuring windows equally. The short wavelength transmission within the measuring window reaches 0 before the long wavelength does so, resulting in a non-linearity between the tension $\mathrm{V}_{\mathrm{x}}$ and the effective $\mathrm{CO}_{2}$ cell concentration. The alarm threshold of the optical sensor operating in natural site was fixed at $1000 \mathrm{ppm}$ but to spread out its capability to broad $\mathrm{CO}_{2}$ concentration range, the adjustable measurement cell presented in Figure 3 has been developed, and used for in-deep measurements in natural sites. One of the advantages of a Mid-IR optical sensor is its reproducibility and stability. The reproducibility has been tested on the various $\mathrm{CO}_{2}$ concentrations by a series of successive measurements showing very good stability over time of the Mid-IR sensor. Over a period of 3 hours of detection, the signal remains within the range of $1 \%$ compared to a mean value.

At Ste-Marguerite site (Puy-de-Dôme, France), a first experiment has been done to evaluate the outside behavior of the miniaturized $\mathrm{CO}_{2}$ optical sensor and to investigate its response at low-lying depths. It was introduced in $1.5 \mathrm{~m}$ deep wells with high $\mathrm{CO}_{2}$ concentration (75000 ppm) (Figure 5). The output signal is directly compared with the value perform by a commercial optical sensor LFG20 from ADC Gas Analysis Ltd. These experiments demonstrate the repeatability and the stability of the optical sensor in environmental conditions.

The next step consisted in an experimentation of $\mathrm{CO}_{2}$ detection in a deeper well at Forbach (Moselle, France). The $\mathrm{CO}_{2}$ optical sensor had been mounted on a crane, and the $100 \mathrm{~m}$ 
electrical and optical wire coils were located aside the home-made tripod (Figure 6). The field operation presented here consisted in moving down the device in the well up to a depth of 90 $\mathrm{m}$. First the sensor is calibrated at a depth of $5 \mathrm{~m}$ by injection of $\mathrm{CO}_{2}$ and $\mathrm{N}_{2}$ gas. The calibration is done with commercial detectors LFG20 from ADC Gas Analysis Ltd and G110 from Geotech. After that the Mid-IR optical sensor is moving to $90 \mathrm{~m}$ and $\mathrm{CO}_{2}$ concentration is measured, to modify this concentration $\mathrm{CO}_{2}$ and $\mathrm{N}_{2}$ gases are injected. The sensor response is much faster than GLF20 and G110 because the $\mathrm{CO}_{2}$ concentration detection can be directly done in the bottom well for the Mid-IR optical sensor. This kind of commercial detector is based on gas extraction from the bottom to the surface, their pumping capacity is low and the waiting time for the measurement is several minutes. The Mid-IR optical sensor is lowered into the well to $90 \mathrm{~m}$. As the $\mathrm{CO}_{2}$ concentration in the well does not change significantly, $\mathrm{CO}_{2}$ gas is injected to study the dynamic behavior of the optical sensor monitoring the evolution of the concentration over time (Figure 7). Each gas injection takes about 1 minute and there is a rapid increase followed by a slow decrease in concentration due to diffusion time of the gas in the well. After few hours of measurement, the detector is then reached back to the surface at a speed of 1.1 meter per minute while recording the $\mathrm{CO}_{2}$ concentration (Figure 8). The $\mathrm{CO}_{2}$ detection monitoring started from the bottom of the well, but gave a meaningless measurement, as the detector was working out of its operating range. The variation of concentration along the well is related to the gas injection during the measurement and its diffusion.

The uncertainty of the measurement depends on the concentration range obtained by calculation of the ratio of a differential signal $\mathrm{V}(\mathrm{x})$ and $\mathrm{V}_{\mathrm{b}}$. The uncertainty on the ratio becomes large when the signal $\mathrm{V}(\mathrm{x})$ becomes close to the background value $\mathrm{V}_{\mathrm{b}}$. The concentration depends logarithmically on the ratio $\mathrm{R}(\mathrm{x})$, the uncertainty relation is not linear with the concentration. Under the used experimental conditions, it can be considered, for low 
$\mathrm{CO}_{2}$ concentrations, that the response is about $500 \mathrm{ppm}$ to less than $2 \%$ of $\mathrm{CO}_{2}$ concentration. For higher concentration, the sensitivity is of $1000 \mathrm{ppm}, 5000 \mathrm{ppm}$ and $50000 \mathrm{ppm}$ for $5 \%, 10$ $\%$ and $50 \% \mathrm{CO}_{2}$ concentrations, respectively.

To improve the precision and the sensitivity, different ways are possible. In the present configuration, the length of the cell can be adjusted for matching to higher or lower concentration (Figure 3). For very low concentration, it will be possible to use a multi-path cell. For high concentration, it is quite possible to measure concentrations by moving the detection wavelength of $\mathrm{CO}_{2}$ on the edge of the absorption band to limit the saturation effect explained previously (see 3.2.2). Nevertheless, the limitation corresponds to the width of the used filter of about $200 \mathrm{~nm}$ FWHM, largely encompassing the absorption band. A better solution will be to use fixed passive interferential filters. A sensor evolution was to use a bundle of fiber to collect light and some tests were made using six undoped fibers assembled in the SMA connector around the doped fiber. This solution has enabled a better collection of the light after passing through the gas cell and the refocusing lens, thereby increasing the signal on the detector.

\section{Conclusion}

We have demonstrated in this study that the $\mathrm{Dy}^{3+}$ doped $\mathrm{Ga}_{5} \mathrm{Ge}_{20} \mathrm{Sb}_{10} \mathrm{~S}_{65}$ fiber luminescence can be successfully used for the $\mathrm{CO}_{2}$ detection, suitable for on-the-field operations in order to monitor reservoirs, aquifers and wells for a long-term period in order to potentially detect leaks occurring during the $\mathrm{CO}_{2}$ injection or appearing during the storage. From the $920 \mathrm{~nm}$ laser diode pumping, the optical fiber quality of this $\mathrm{Dy}^{3+}: \mathrm{Ga}_{5} \mathrm{Ge}_{20} \mathrm{Sb}_{10} \mathrm{~S}_{65}$ leaded to an efficient $4.35 \mu \mathrm{m}$ luminescence from the ${ }^{6} \mathrm{H}_{11 / 2}$ to ${ }^{6} \mathrm{H}_{13 / 2}$ manifold, as the phonon energy of the sulfide glasses gives a favorable global quantum yield. The preliminary 
laboratory experiments allow manufacturing an optical sensor based on $\mathrm{Dy}^{3+}: \mathrm{Ga}_{5} \mathrm{Ge}_{20} \mathrm{Sb}_{10} \mathrm{~S}_{65}$

for field operations. After several upgrades and a calibration, measurement campaigns on low-lying $\mathrm{CO}_{2}$ sites and in-deep operation at a depth of 90 meters have been performed. This optical sensor exhibits a good temporal response and time stability. These first results are very promising, differed kind of improvement can be done to realize a very robust and efficient commercial sensor.

Such a detection technique based on mid-IR fluorescence of rare earth doped $\mathrm{Ga}_{5} \mathrm{Ge}_{20} \mathrm{Sb}_{10} \mathrm{~S}_{65}$ fibers and differential detection could be suitable for many other gases having absorption bands in the mid-IR spectral domain, as much as an overlap exists between a rare-earth midIR emission and pollutant absorption band like $\mathrm{H}_{2} \mathrm{~S}, \mathrm{CH}_{4}$ or $\mathrm{NO}_{\mathrm{x}}$.

\section{Acknowledgements:}

This work was supported by ADEME agency and the ANR French research programs Optique $\mathrm{CO}_{2}$ (2008-2012) and CGS $\mu$ lab (2012-2016). 


\section{REFERENCES}

[1] H. Segawa, E. Ohnishi, Y. Arai, K. Yoshida, Sensitivity of fiber-optic carbon dioxide sensors utilizing indicator dye, Sensors and Actuators B-Chemical, 94 (2003) 276-281.

[2] K. Ertekin, I. Klimant, G. Neurauter, O.S. Wolfbeis, Characterization of a reservoir-type capillary optical microsensor for pCO(2) measurements, Talanta, 59 (2003) 261-267.

[3] R.N. Dansby-Sparks, J. Jin, S.J. Mechery, U. Sampathkumaran, T.W. Owen, B.D. Yu, K. Goswami, K.L. Hong, J. Grant, Z.L. Xue, Fluorescent-Dye-Doped Sol-Gel Sensor for Highly Sensitive Carbon Dioxide Gas Detection below Atmospheric Concentrations, Anal. Chem., 82 (2010) 593-600.

[4] M. Blomberg, A. Torkkeli, A. Lehto, C. Helenelund, M. Viitasalo, Electrically tuneable micromachined Fabry-Perot interferometer in gas analysis, Phys. Scr., T69 (1997) 119-121.

[5] T. Schweizer, Hewak, D. W., Samson, B. N., Payne, D. N., Spectroscopy of potential midinfrared laser transitions in gallium lanthanum sulphide glass, J. Lumin., $72-4$ (1997) 419-421.

[6] Y.B. Shin, J. Heo, Mid-infrared emissions and energy transfer in Ge-Ga-S glasses doped with Dy3+, J. Non-Cryst. Solids, 257 (1999) 260-265.

[7] L.B. Shaw, Cole, B., Thielen, P. A., Sanghera, J. S., Aggarwal, I. D. , Mid-wave IR and long-wave IR laser potential of rare-earth doped chalcogenide glass fiber, IEEE J. Quantum Electron., 37 (2001) 1127-1137.

[8] B.J. Park, H.S. Seo, J.T. Ahn, Y.G. Choi, J. Heo, W.J. Chung, Dy(3+) doped Ge-Ga-Sb-Se glasses and optical fibers for the mid-IR gain media, J. Ceram. Soc. Jpn., 116 (2008) 10871091.

[9] M. Ichikawa, Y. Ishikawa, T. Wakasugi, K. Kadono, Near- and mid-infrared emissions from Dy3+ and Nd3+-doped Ga2S3-GeS2-Sb2S3 glass, Optical Materials, 35 (2013) 19141917.

[10] F. Charpentier, F. Starecki, J.L. Doualan, P. Jovari, P. Camy, J. Troles, S. Belin, B. Bureau, V. Nazabal, Mid-IR luminescence of Dy3+ and Pr3+ doped Ga5Ge20Sb10S(Se)(65) bulk glasses and fibers, Mater. Lett., 101 (2013) 21-24.

[11] V. Moizan, Nazabal,V., Troles, J., Houizot, P., Adam, J.-L., Smektala, F., Gadret,G., Pitois, S., Doualan, J.-L., Moncorgé,R., Canat, G., Er3+-doped GeGaSbS glasses for mid-IR fibre laser application: Synthesis and rare earth spectroscopy, Optical Material, 31 (2008) 3946.

[12] J.S. Sanghera, L.B. Shaw, I.D. Aggarwal, Chalcogenide Glass-Fiber-Based Mid-IR Sources and Applications, IEEE J. Sel. Top. Quantum Electron., 15 (2009) 114-119.

[13] J. Charrier, M.L. Anne, H. Lhermite, V. Nazabal, J.P. Guin, F. Charpentier, T. Jouan, F. Henrio, D. Bosc, J.L. Adam, Sulphide Ga(x)Ge(25-x)Sb(10)S(65(x=0,5)) sputtered films: Fabrication and optical characterizations of planar and rib optical waveguides, J. Appl. Phys., 104 (2008).

[14] V. Moizan, V. Nazabal, J. Troles, P. Houizot, J.L. Adam, J.L. Doualan, R. Moncorge, F. Smektala, G. Gadret, S. Pitois, G. Canat, Er3+-doped GeGaSbS glasses for mid-IR fibre laser application: Synthesis and rare earth spectroscopy, Optical Materials, 31 (2008) 39-46.

[15] V. Nazabal, P. Camy, P. Nemec, H. Lhermite, J. Charrier, J.L. Doualan, S. Zhang, M. Frumar, J.L. Adam, Erbium doped germanium based sulphide optical waveguide amplifier for near and mid-IR, in: A. Serpenguzel, G. Badenes, G.C. Righini (Eds.) Proceedings of SPIE, Photonic Materials, Devices, and Applications, 2009.

[16] V. Nazabal, P. Nemec, J. Jedelsky, C. Duverger, J. Le Person, J.L. Adam, M. Frumar, Dysprosium doped amorphous chalcogenide films prepared by pulsed laser deposition, Optical Materials, 29 (2006) 273-278. 
[17] V. Nazabal, P. Nemec, A.M. Jurdyc, S. Zhang, F. Charpentier, H. Lhermite, J. Charrier, J.P. Guin, A. Moreac, M. Frumar, J.L. Adam, Optical waveguide based on amorphous Er3+doped Ga-Ge-Sb-S(Se) pulsed laser deposited thin films, Thin Solid Films, 518 (2010) 49414947.

[18] V. Nazabal, A.-M. Jurdyc, P. Nemec, M.-L. Brandily-Anne, L. Petit, K. Richardson, P. Vinatier, C. Bousquet, T. Cardinal, S. Pechev, J.-L. Adam, Amorphous Tm3 + doped sulfide thin films fabricated by sputtering, Optical Materials 33 (2010) 220-226.

[19] B.R. Judd, Optical Absorption Intensities of Rare-Earth Ions, Phys. Rev. A, 127 (1962) 750.

[20] G.S. Ofelt, Intensities of Crystal Spectra of Rare-Earth Ions, The Journal of Chemical Physics, 37 (1962) 511-520.

[21] D.W. Hewak, B.N. Samson, J.A.M. Neto, R.I. Laming, D.N. Payne, Emission at 1.3-MuM from Dysprosium-Doped Galas Glass, Electron. Lett., 30 (1994) 968-970.

[22] Y.B. Shin, J. Heo, Mid-infrared emissions and multiphonon relaxation in Dy3+-doped chalcohalide glasses, J. Non-Cryst. Solids, 253 (1999) 23-29.

[23] S.D. Pangavhane, P. Němec, V. Nazabal, A. Moreac, P. Jóvári, J. Havel, Laser desorption ionization time-of-flight mass spectrometry of erbium-doped $\mathrm{Ga}-\mathrm{Ge}-\mathrm{Sb}-\mathrm{S}$ glasses, Rapid Commun. Mass Spectrom., 28 (2014) 1221-1232.

[24] V.G. Truong, Ham, B. S., Jurdyc, A. M., Jacquier, B., Leperson, J., Nazabal, V., Adam, J. L., Relaxation properties of rare-earth ions in sulfide glasses: Experiment and theory, Physical Review B, 74 (2006) 184103-184101. 


\section{Biographies}

F. Starecki received his Ph.D. degree from the University of Caen, France, in 2013. His work was focused on visible and near-infrared laser emitting waveguides, grown by the liquid phase epitaxy technique (LPE). Now he is working as a post-doctoral associate at the Chemical Sciences Institute (ISCR) on mid-IR optical sensor for detection of $\mathrm{CO}_{2}$.

F. Charpentier defended his $\mathrm{PhD}$, focused on the infrared optical fibers and thin films development dedicated to monitoring $\mathrm{CO}_{2}$ in storage wells, at the University of Rennes in 2009. In 2010, he got the Rennes 1 foundation award for this work. He is the author and coauthor of about 15 publications and a patent. In 2012, he joined DIAFIR company and he is now in charge of the development of chemical and biological sensors using chalcogenide fibers.

J.-L. Doualan is CNRS researcher in the group MIL of the CIMAP laboratory. He has got the Doctorat es Sciences Physiques degree in 1988, on the study of colour center lasers, his research interest then turned to the fabrication, the spectroscopy and the laser applications of the rare earth doped laser materials. He is currently working on Mid-IR sensors based on rare earth doped chalcogenide fibers for detection of specific chemical species. He has been an author or a co-author of more than 200 articles and four patents.

L. Quétel received a Master in Optical-Electronical engineering in 1994 from Rennes I University and Ph. D. degrees in optical engineering in 1997 From Lilles University. From 1998 to 2003, he was Fiber Bragg Grating project manager in Highwave Optical 
Technologies (France). Since 2004, he is the Optical Component manager in IDIL Fibres Optiques (France).

K. Michel is a scientific researcher at BRGM. She holds a PhD in Chemistry from University of Rennes. Her thesis is entitled "Infrared fiber optical sensor dedicated to detection of water pollution". She has been involved on $\mathrm{CO}_{2}$ storage since the Weyburn, Geocarbone monitoring, Sentinelle, Optique $\mathrm{CO}_{2}$ projects. She participates to various European and national $\mathrm{CO}_{2}$ storage projects, including $\mathrm{CO}_{2} \mathrm{GeoNet}$. Her key qualifications are: chemistry, soil gas, monitoring, sensors and mineral characterization.

R. Chahal is a PhD student at the Chemical Sciences Institute (ISCR) at the University of Rennes, France. The subject of his thesis, supervised by Prof. Bruno Bureau and Dr. Virginie Nazabal, is devoted to the development of mid-IR optical sensors based on chalcogenide glasses applied for detection and monitoring of $\mathrm{CO}_{2}$.

A. Braud is Associate Professor at the University of CAEN (France). He received his $\mathrm{PhD}$ in Physics in 1999. He was a Post-doc at Montana State University (Bozeman, Montana, USA) and worked after as a Research Contractor at NASA Langley Research Center (USA) developing high power lasers for LIDAR applications. In 2008, he was a visiting Professor at Boston College, USA. A.Braud's research concentrates on rare earth and transition metal doped materials for laser, lighting and photovoltaic applications. He is author and co-author of two chapter books and more than 50 papers in scientific journals with referees.

P. Camy received the Master degree from the Institut d'Optique in Paris in 1993 and the Doctorate degree in Physics at the University of Pierre et Marie Curie (Paris) in 1996. He is now full professor at the University of Caen, assistant director of the CIMAP laboratory and team leader of the group "Matériaux et Instrumentation Laser". He is involved in projects 
concerning rare earth doped materials for lasers and sensors applications. He is author or coauthor of more than 80 articles in scientific journals, co-inventor of 4 patents and Associate Editor for Optics Express Journal of the OSA.

J. Troles is Professor at the University of Rennes. He received the Ph.D. degree in chemistry in 2002 from the University of Rennes, France. The subject of the thesis was "synthesis and characterization of high nonlinear chalcogenide glasses for telecommunication and military applications". In 2003, he joined the Glasses and Ceramics team in Rennes. His research activities include the synthesis, the linear and the nonlinear characterizations of the chalcogenide glasses and fibers. Since 2004, he works on the preparation of pure chalcogenide fibers and more particularly on microstructured fibers for applications in the near and the mid-infrared.

B. Bureau, $\mathrm{PhD}$, "Local order investigations in fluoride glasses by multinuclear solid state NMR", defended on 1998 at the University of Le Mans (France). From 1999 to 2006, he was Associated Professor in the "Glasses and Ceramics Laboratory" of the University of Rennes. After his accreditation to supervise research devoted to "optical and structural properties of non-conventional glasses", he is Full Professor in charge of the passive optic group working on infrared optical fibers for sensors. He is also a solid-state NMR expert and is responsible for several international research programs. $\mathrm{He}$ is author and co-author of about 100 publications and more than 20 invited lectures.

V. Moizan, defended her PhD in 2008 ("Amplification study in band II in chalcogenide fiber") after a master degree at the University of Rennes. She is working at IFP, Innovating for energy as engineer of research at Physics and Analysis Division. She is author and co- 
author of at least 20 publications. Her skills and expertise concern applied chemistry, materials chemistry and catalysis.

V. Nazabal got her PhD degree in Solid State Chemistry from the University of Bordeaux (France) in 1999 after a master at Ecole Normale Superieure, at University of Paris VI. She joined the NIMS (Tsukuba, Japan) as post-doctoral fellowship in 2000. She belongs to the CNRS since 2001 and got accreditation in 2009. Her research activity is performed at the Glasses \& Ceramics team of the Chemical Sciences Institute at the University of Rennes (France) with more than 100 publications as author or co-author and several invited contributions in international conferences. She received in 2010 a bronze medal of CNRS. 
Table 1. Transition parameters of the $\mathrm{Ga}_{5} \mathrm{Ge}_{20} \mathrm{Sb}_{10} \mathrm{~S}_{65}$ : $\mathrm{Dy}^{3+}$ glass, estimated by a Judd-Ofelt analysis. Transitions with a branching ratio less than $5 \%$ are not listed $(\lambda$; wavelength, $\tau(\mathrm{rad})$ radiative lifetime, $\beta$; branching ratio, $\tau(\mathrm{NR})$; non-radiative lifetime (multiphonon relaxations), $\eta$; quantum efficiency).

Table 2. calculated and experimental fluorescence lifetimes for the $\mathrm{Dy}^{3+}$ ion in $\mathrm{Ga}_{5} \mathrm{Ge}_{20} \mathrm{Sb}_{10} \mathrm{~S}_{65}$ glasses. $\tau_{\text {fwo }}(j 0)=\tau_{\text {rad }} \eta$ 
Table 1.

\begin{tabular}{|c|c|c|c|c|c|}
\hline Transition & $\lambda_{\mathrm{em}}(\mathrm{nm})$ & $\mathrm{T}_{\text {rad }}(\mathrm{ms})$ & $\beta(\%)$ & $\mathrm{T}_{\mathrm{NR}}(\mathrm{ms})$ & $\eta(\%)$ \\
\hline${ }^{6} \mathrm{H}_{13 / 2} \rightarrow{ }^{6} \mathrm{H}_{15 / 2}$ & 2888.0 & 7.03 & 100 & $9 \mathrm{E}+03$ & $99.9 \%$ \\
\hline $\begin{aligned}{ }^{6} \mathrm{H}_{11 / 2} & \rightarrow{ }^{6} \mathrm{H}_{15 / 2} \\
& \rightarrow{ }^{6} \mathrm{H}_{13 / 2}\end{aligned}$ & $\begin{array}{l}1718.5 \\
4243.7\end{array}$ & 2.31 & $\begin{array}{l}91.2 \% \\
8.8 \%\end{array}$ & 4.11 & $64.0 \%$ \\
\hline $\begin{aligned}{ }^{6} \mathrm{H}_{9 / 2},{ }^{6} \mathrm{~F}_{11 / 2} & \rightarrow{ }^{6} \mathrm{H}_{15 / 2} \\
& \rightarrow{ }^{6} \mathrm{H}_{13 / 2}\end{aligned}$ & $\begin{array}{l}1302 \\
2370.9\end{array}$ & 0.19 & $\begin{array}{l}90.8 \% \\
8.5 \%\end{array}$ & 0.13 & $41.1 \%$ \\
\hline $\begin{aligned}{ }^{6} \mathrm{H}_{7 / 2},{ }^{6} \mathrm{~F}_{9 / 2} & \rightarrow{ }^{6} \mathrm{H}_{15 / 2} \\
& \rightarrow{ }^{6} \mathrm{H}_{13 / 2}\end{aligned}$ & $\begin{array}{l}1111.0 \\
1805.6\end{array}$ & 0.23 & $\begin{array}{l}60.7 \% \\
35.3 \%\end{array}$ & 0.003 & $1.3 \%$ \\
\hline${ }^{6} \mathrm{~F}_{7 / 2} \rightarrow{ }^{6} \mathrm{H}_{15 / 2}$ & 917.0 & & $72.1 \%$ & & 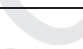 \\
\hline $\begin{array}{l}\rightarrow{ }^{6} \mathrm{H}_{13 / 2} \\
\rightarrow{ }^{6} \mathrm{H}_{11 / 2}\end{array}$ & $\begin{array}{l}1343.6 \\
1966.1\end{array}$ & 0.20 & $\begin{array}{l}8.62 \% \\
15.96 \%\end{array}$ & 0.17 & $46.8 \%$ \\
\hline
\end{tabular}


Table 2.

$\begin{array}{lllll} & \mathrm{T}_{\text {fluo }}(\mathrm{JO}) & \begin{array}{c}\mathrm{T}_{\text {fluo }}(\exp ) \\ 1000 \mathrm{ppm}\end{array} & \begin{array}{l}\mathrm{T}_{\text {fluo }}(\exp ) \\ 5000 \mathrm{ppm}\end{array} & \begin{array}{l}\mathrm{T}_{\text {fluo }}(\exp ) \\ 10000 \mathrm{ppm}\end{array} \\ { }^{6} \mathrm{H}_{7 / 2} & 3 \mu \mathrm{s} & 3 \mu \mathrm{s} & 3 \mu \mathrm{s} & 3 \mu \mathrm{s} \\ { }^{6} \mathrm{H}_{9 / 2} & 76 \mu \mathrm{s} & 34 \mu \mathrm{s} & 28 \mu \mathrm{s} & 18 \mu \mathrm{s} \\ { }^{6} \mathrm{H}_{11 / 2} & 1.47 \mathrm{~ms} & 1.3 \mathrm{~ms} & 1.4 \mathrm{~ms} & 0.6 \mathrm{~ms} \\ { }^{6} \mathrm{H}_{13 / 2} & 7.0 \mathrm{~ms} & 5.6 \mathrm{~ms} & 4.2 \mathrm{~ms} & --\end{array}$


Figure 1. Absorption cross-section spectrum of $\mathrm{Dy}^{3+}$ doped $\mathrm{Ga}_{5} \mathrm{Ge}_{20} \mathrm{Sb}_{10} \mathrm{~S}_{65}$, the inset shows the $\mathrm{Dy}^{3+}$ energy diagram.

Figure 2. $\mathrm{Dy}^{3+}$ fluorescence spectrums from a $915 \mathrm{~nm}$ pumping. A: 1250-2000 and 2600$3400 \mathrm{~nm}$ fluorescence spectrums. B: emission band around $4.3 \mu \mathrm{m}$ with and without $\mathrm{CO}_{2}$ absorption (respectively black and red line).

Figure 3. Extraction of a representative value of the $\mathrm{CO}_{2}$ concentration from the measurement of the pyroelectric detector electric signal $\mathrm{V}(\mathrm{x}), \mathrm{V}_{\text {ref }}$ or $\mathrm{V}_{\mathrm{b}}$.

Figure 4. Compacted $\mathrm{CO}_{2}$ optical sensor head, scheme and picture.

Figure 5. First field operations, consisting in underlying $\mathrm{CO}_{2}$ measurements by the optical sensor based on $\mathrm{Dy}^{3+}: \mathrm{Ga}_{5} \mathrm{Ge}_{20} \mathrm{Sb}_{10} \mathrm{~S}_{65}$ fiber dipped into a well (1.5 m).

Figure 6. Optical $\mathrm{CO}_{2}$ sensor based on $\mathrm{Dy}^{3+}: \mathrm{Ga}_{5} \mathrm{Ge}_{20} \mathrm{Sb}_{10} \mathrm{~S}_{65}$ fiber craned in the $90 \mathrm{~m}$-deep $\mathrm{CO}_{2}$ well using a tripod.

Figure 7. Influence of the gas injection on the $\mathrm{CO}_{2}$ concentration at bottom of the well $(90 \mathrm{~m})$

Figure 8. $\mathrm{CO}_{2}$ sensor recording data when the sensor moves from bottom to the surface of the well. 
- Highlights

- Optical $\mathrm{CO}_{2}$ detection

- Rare earth doped chalcogenide fibers

- Dy : glass sulfide spectroscopy

- Mid-IR amplified spontaneous emission (ASE) sources

- Field operating sensor 


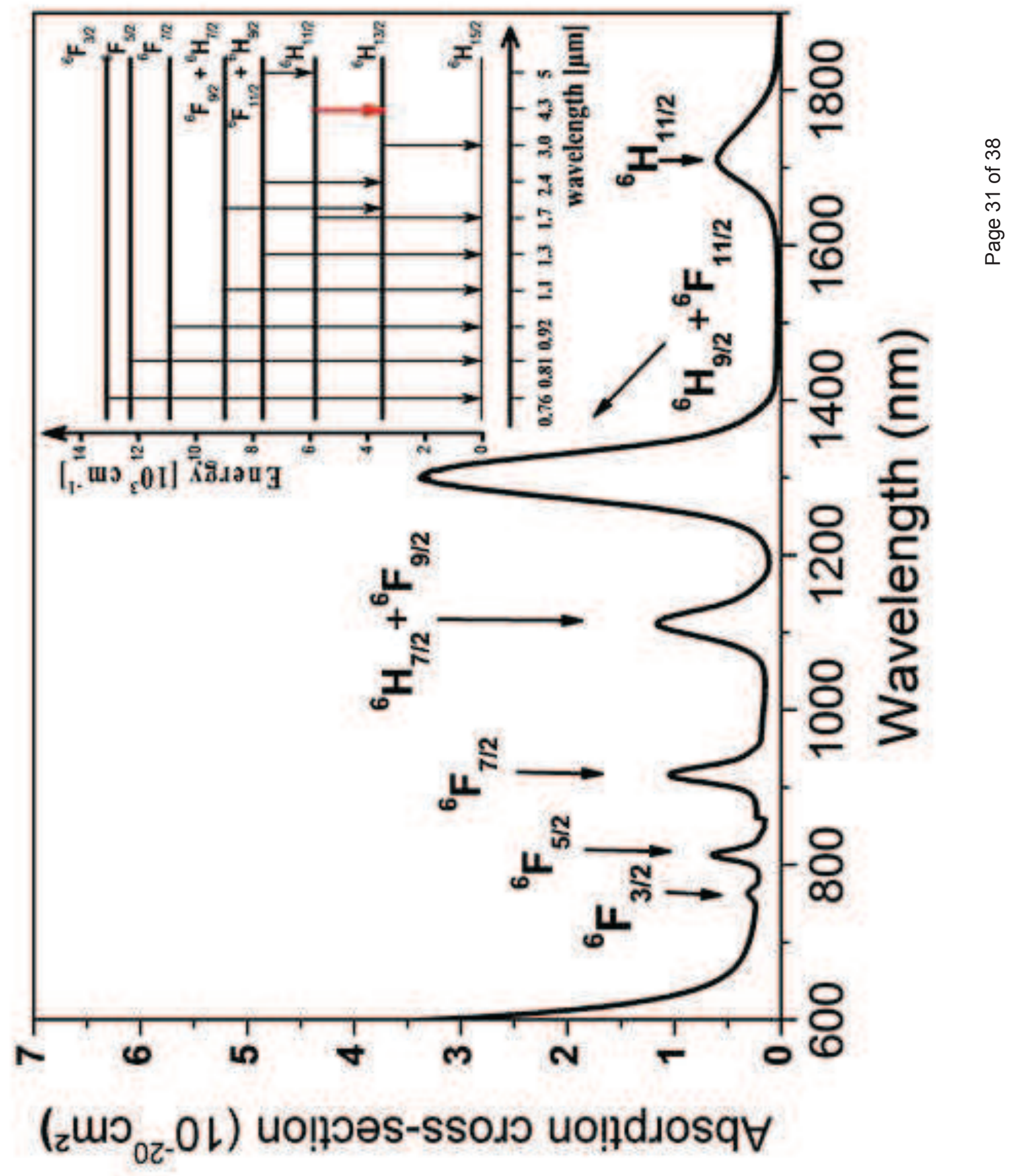




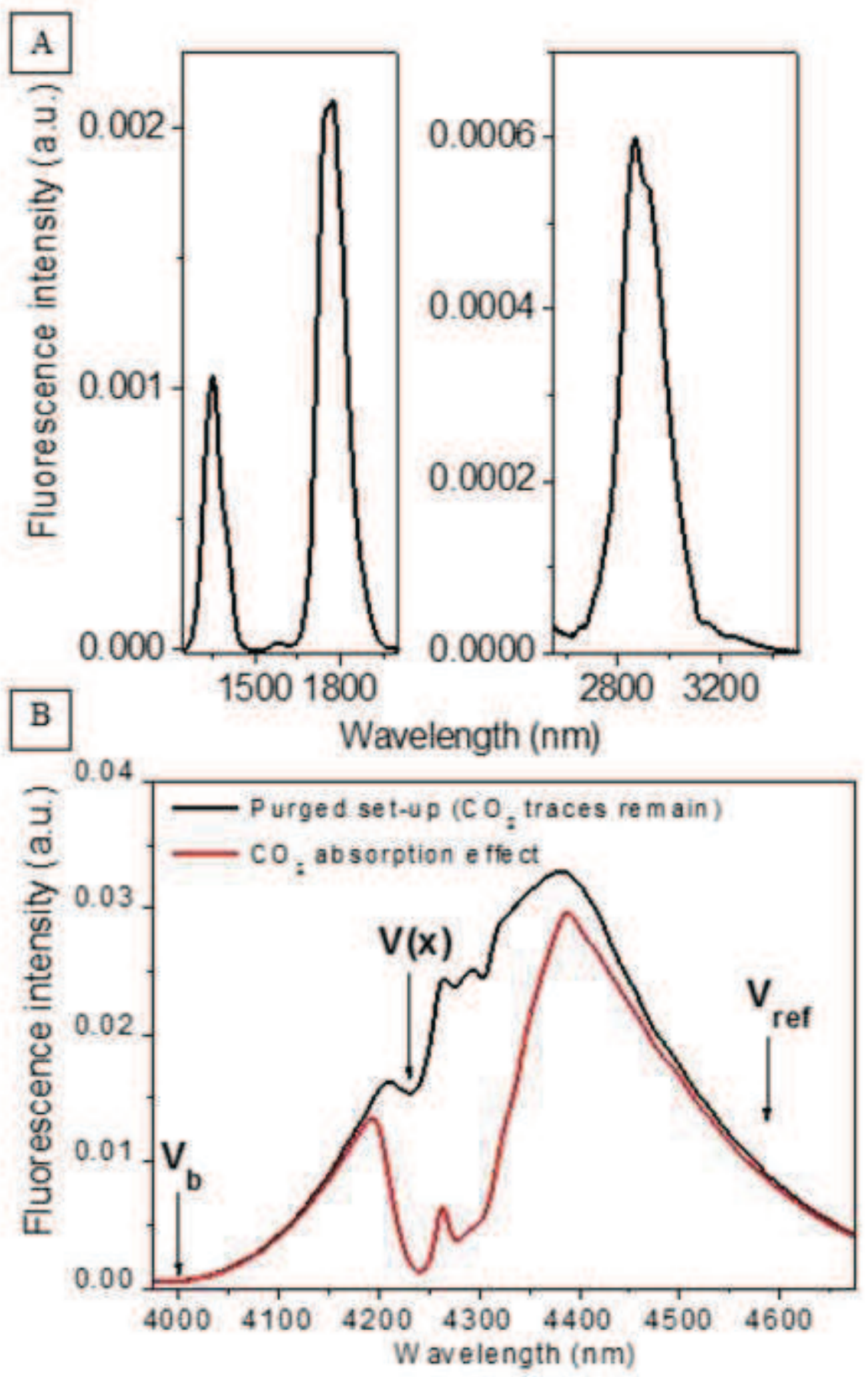




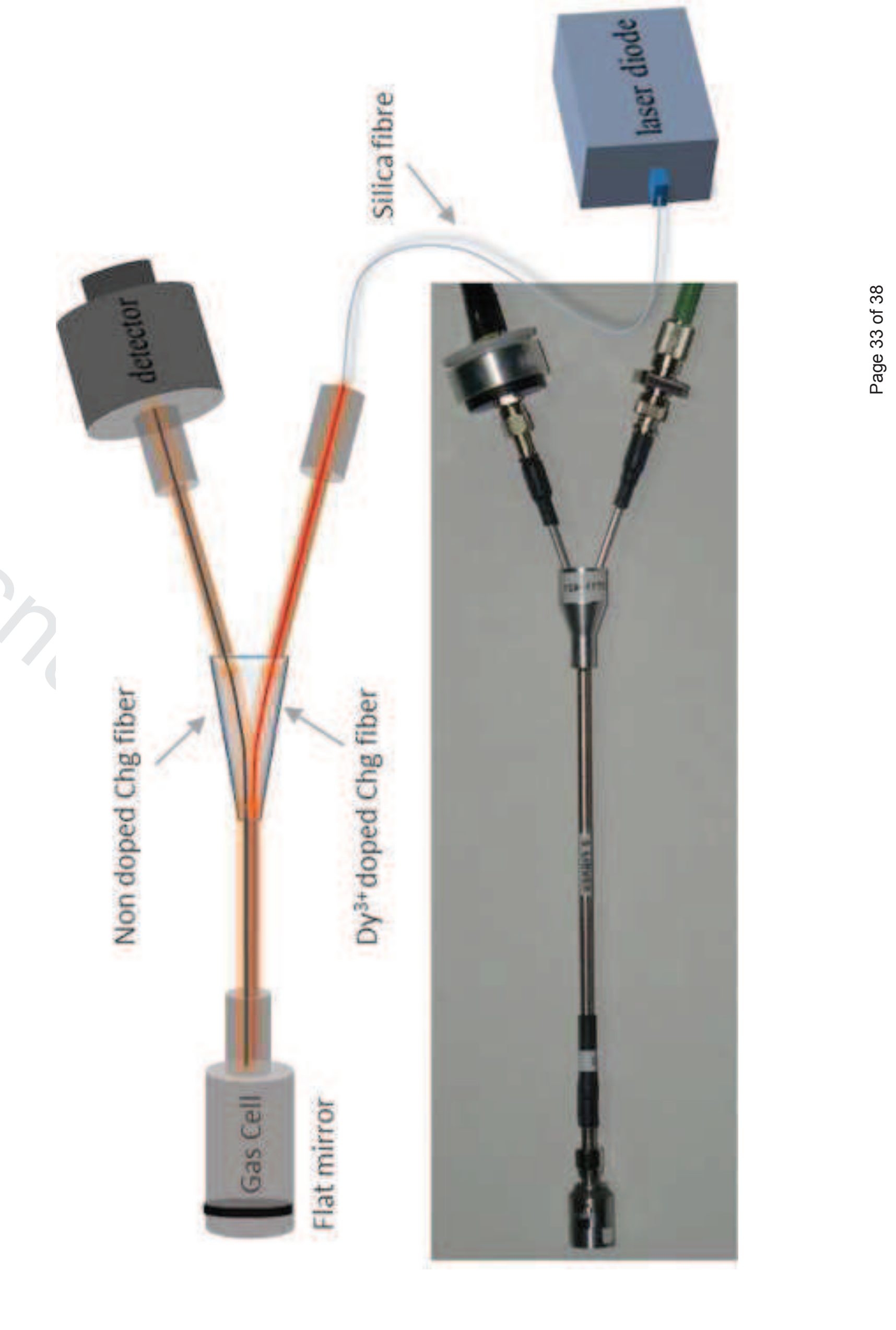






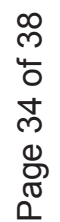




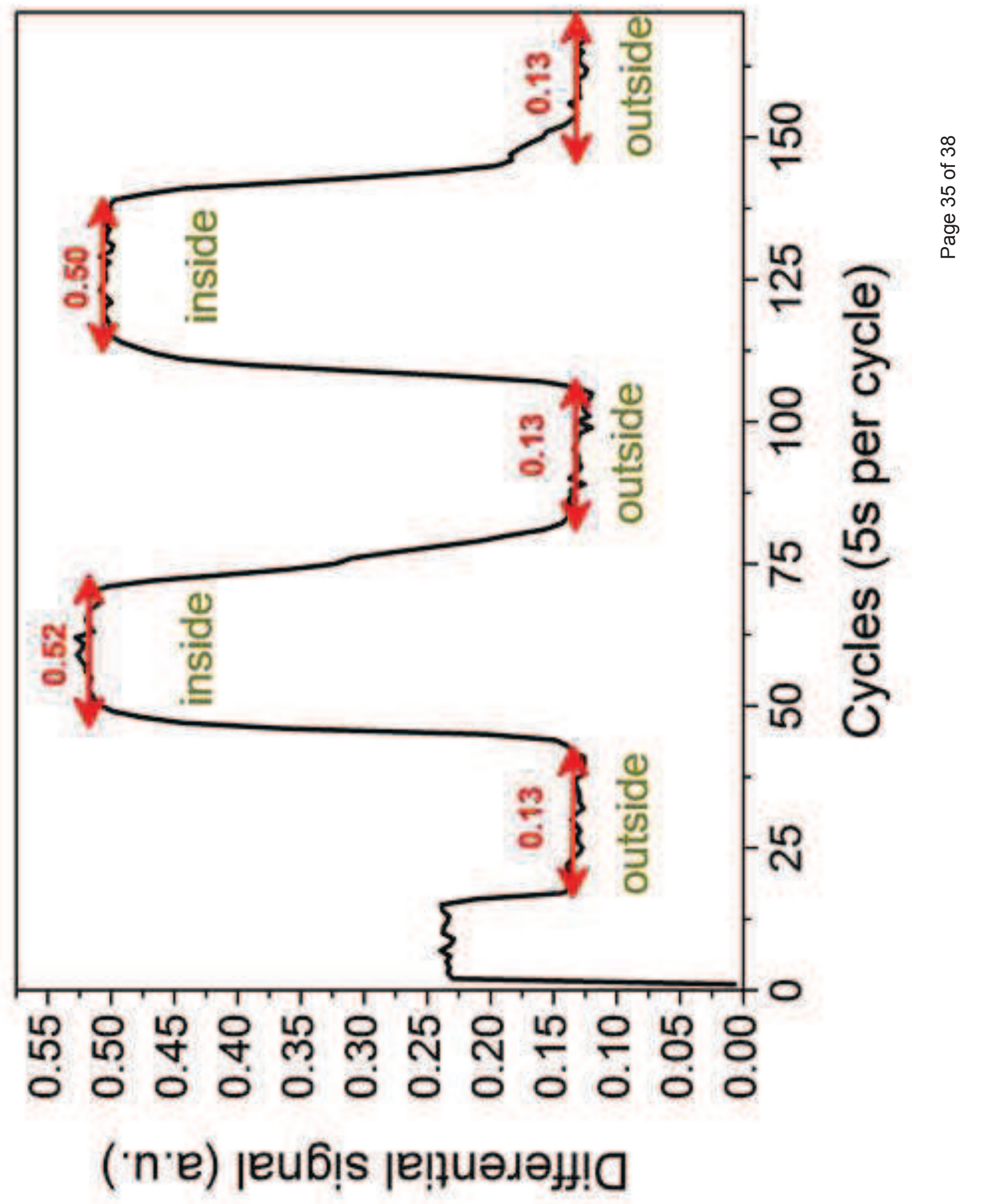




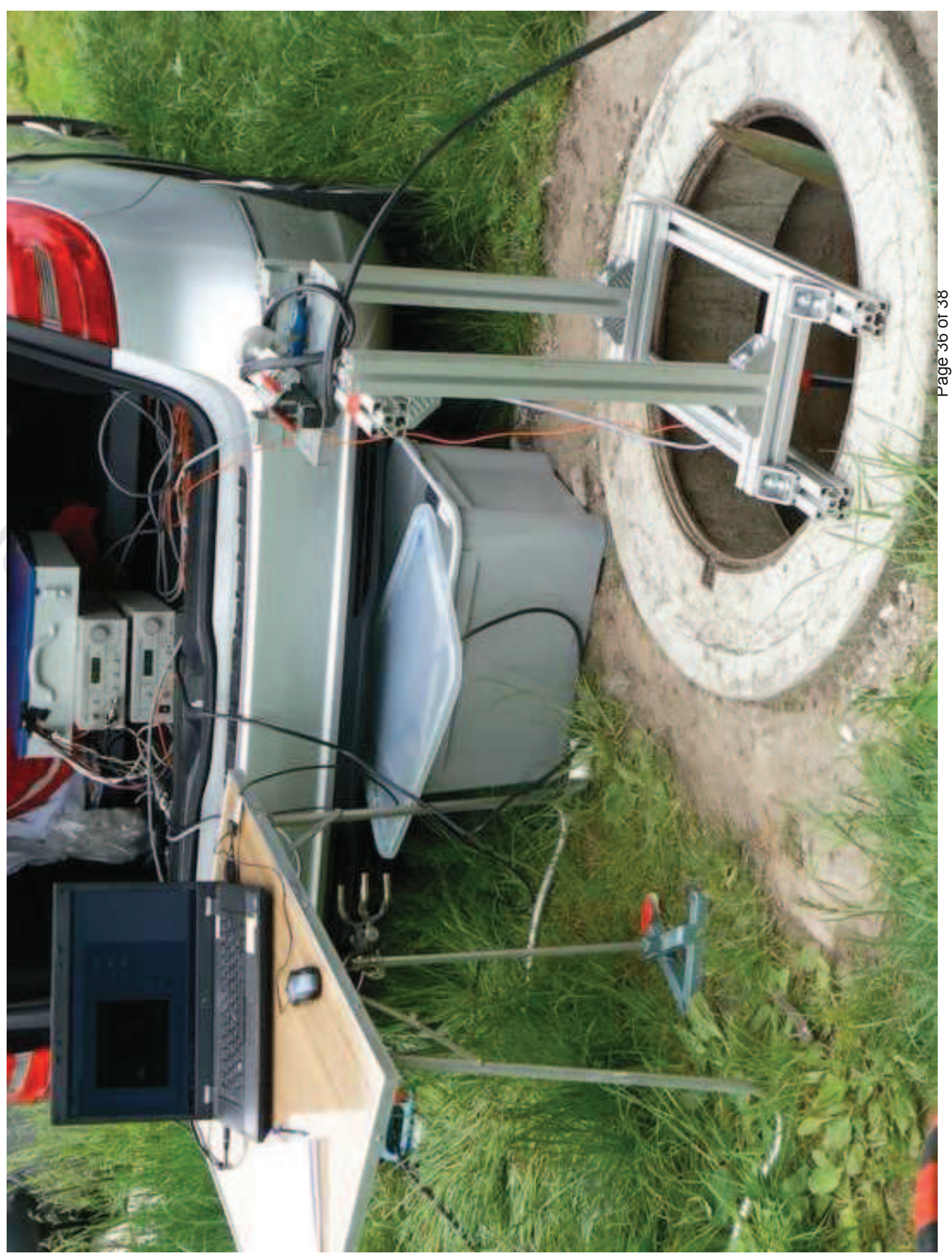

0
0
는
0 


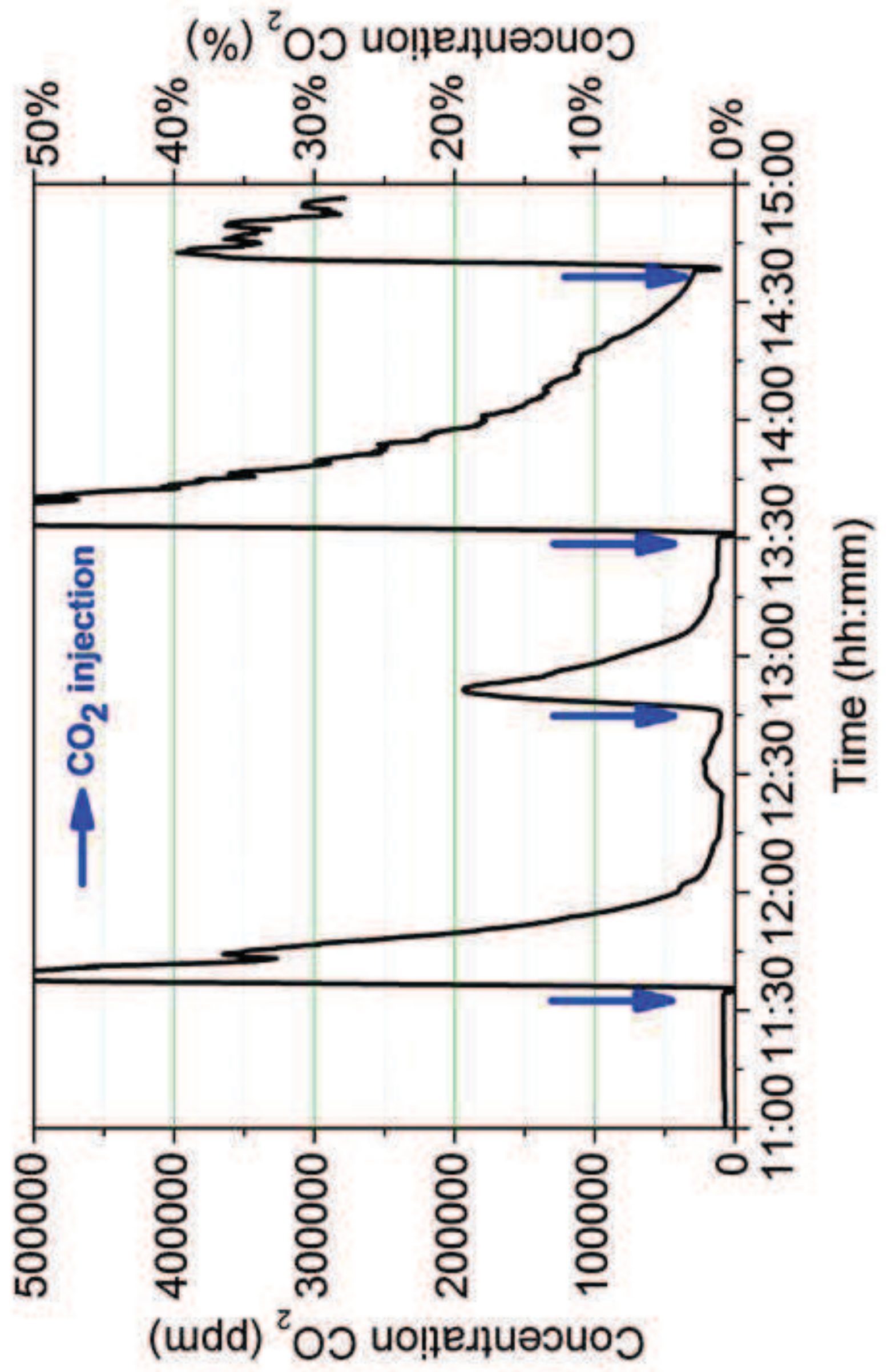

$\infty$
$m$
4
0
0
0
0
0
0
0 


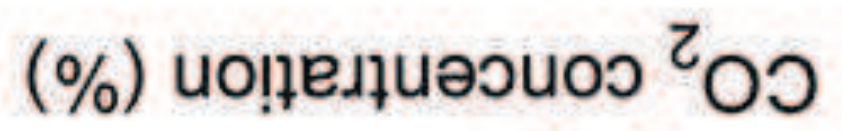

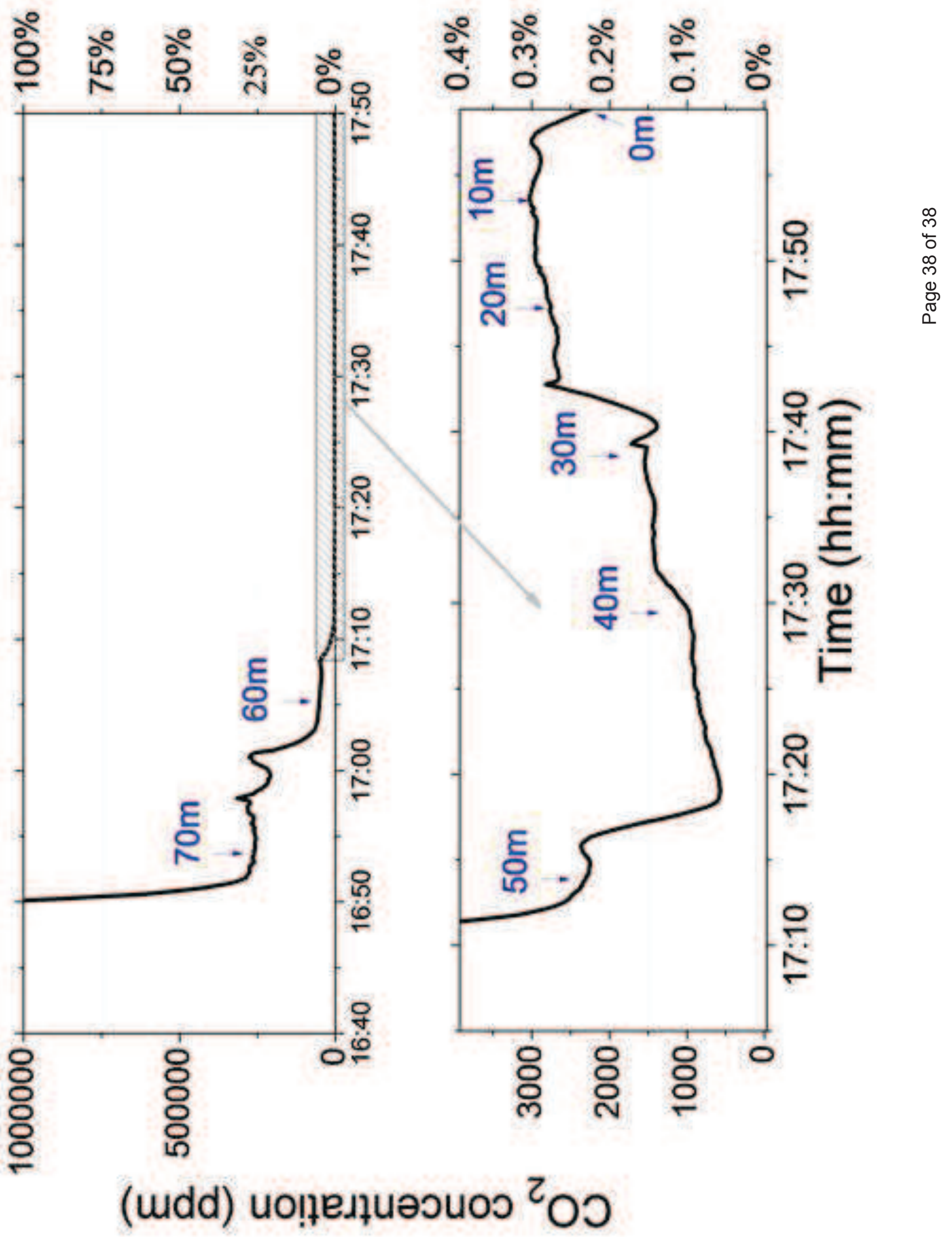

